\title{
Incidence of Postharvest Decay of 'd'Anjou' Pear and Control with a Thiabendazole Drench
}

Cheryl L. Lennox, ARC-Plant Protection Research Institute, Weeds Pathology Unit, Private Bag X5017, Stellenbosch 7599, South Africa; Robert A. Spotts, Oregon State University Mid-Columbia Agricultural Research and Extension Center, Hood River 97031; and Mardé Booyse, ARC-Biometry Unit, Private Bag X5013, Stellenbosch 7599, South Africa

\begin{abstract}
Lennox, C. L., Spotts, R. A., and Booyse, M. 2004. Incidence of postharvest decay of 'd'Anjou' pear and control with a thiabendazole drench. Plant Dis. 88:474-478.

Postharvest decay causes losses to commercial pear industries. The incidence of decay in air and controlled-atmosphere (CA)-stored 'd'Anjou' pear fruit was investigated, and the effect of a prestorage thiabendazole drench on decay in CA-stored fruit was determined. In air storage, bull's-eye rot (31.37\%) was most prevalent in 1996, whereas incidence of gray and blue mold (1996 and 1997) and bull's-eye rot (1997) were similar. Mucor, Alternaria, and Coprinus rot levels were low. Incidence of stem-end gray mold $(2.58 \%)$ was significantly higher than calyxend $(0.73 \%)$ and puncture gray mold $(0.61 \%)$. Incidence of gray mold $(2.26 \%)$ was higher than all other decay in nondrenched CA-storage, and incidence of other decay types were similar. Incidence of puncture gray mold $(1.13 \%)$ was higher than stem-end gray mold $(0.84 \%)$, which in turn was higher than calyx-end gray mold $(0.36 \%)$ in nondrenched CA-storage. Incidence of gray mold $(1.04 \%)$ in CA-stored fruit was reduced by a prestorage thiabendazole drench. Drenching reduced stem-end $(0.34 \%)$ and puncture gray mold $(0.40 \%)$ but had no effect on all other decay or the total decay incidence. These results support the current recommendations of a single postharvest application of thiabendazole to control gray mold in 'd'Anjou' pear fruit.
\end{abstract}

Additional keywords: Botrytis cinerea, Mucor piriformis, Neofabraea spp., Penicillium expansum, Pezicula spp., Phialophora malorum

The largest volume of winter pear fruit (Pyrus communis L.) for fresh consumption in the United States is grown and shipped from packinghouses in Washington and Oregon (19). Of 30 commercial pear fruit packers surveyed in 1993, 22 considered decay as the most serious problem associated with postharvest losses (19). Gray mold (Botrytis cinerea Pers.:Fr.), Mucor rot (Mucor piriformis E. Fisch.), blue mold (Penicillium expansum Link), bull's-eye rot (Neofabraea spp.; synonym Pezicula spp.; 13), and side rot (Phialophora malorum (M. N. Kidd \& A. Beaumont) McColloch) cause serious postharvest losses to pear fruit produced in the Pacific Northwest $(4,7,40)$. Although researchers are aware of the specific organisms responsible for postharvest decay in

Corresponding author: C. L. Lennox

E-mail: vredc1@plant3.agric.za

Use of trade names in this article does not imply endorsement by Oregon State University of the products named or criticism of similar products not mentioned. Oregon Agricultural Experiment Station technical paper 11897.

Accepted for publication 1 December 2003.

Publication no. D-2004-0217-01R

(C) 2004 The American Phytopathological Society the pear cv. d'Anjou, there is little documented information available on the relative importance of the decay organisms in relation to each other and levels of specific decay. In a survey of culled pear fruit conducted by the authors in four packinghouses for the period 1994 to $1996, B$. cinerea caused $55 \%$ of the total decay, whereas Penicillium spp. and Mucor spp. were responsible for 24 and $8 \%$, respectively. The remaining $13 \%$ was ascribed to other pathogens, including Cladosporium spp., Alternaria spp., and Neofabraea spp. (21). In long-term storage, secondary spread of decay from infected fruit to adjacent, previously uninfected fruit poses a significant decay risk.

Methods of handling harvested apple and pear fruit changed dramatically between 1955 and 1965 as immersion dumping in the packinghouses replaced picking lug and dry dumping (5). When large volumes of fruit are dumped, there is a rapid accumulation of dirt and debris, as well as spores of decay pathogens, in the immersion dump water (5) and decay becomes a major problem. Chlorine or sodium orthophenylphenate (SOPP) is added to the dump water to control decay $(6,19,35)$. Systemic benzimidazole fungicides, benomyl and thiabendazole, were introduced into pear packinghouses in the 1970s to control postharvest decay caused by Peni- cillium expansum and B. cinerea $(24,30)$. Initially, losses were reduced to insignificance; however, by 1975, benomyl-resistant strains of $P$. expansum and B. cinerea were found in Oregon and Washington (5). In 1989, all postharvest use of benomyl was removed from the label. Currently, only captan and thiabendazole are registered for postharvest control of decay in pear fruit in the Pacific Northwest. These fungicides are applied as prestorage fruit drenches or line sprays (1). Captan is seldom used because of fungicide residue limits on fruit for the export market.

Current control measures aimed at reducing decay include a preharvest application of ziram and either a postharvest drench or line spray application of thiabendazole. A number of packinghouses have experienced an increase in decay incidence in drenched fruit, particularly decay caused by Penicillium spp. and $\mathrm{Mu}$ cor spp. (5,7). For this reason, the majority of packinghouses apply thiabendazole as a line spray $(19,20)$.

The objectives of this research were to (i) determine the incidence of decay in airstored d'Anjou pear fruit and (ii) determine the effect of a prestorage thiabendazole drench on incidence of decay in commercial controlled-atmosphere (CA)-stored d'Anjou pear fruit.

\section{MATERIALS AND METHODS}

Decay in air storage. Fruit from 14 commercial d'Anjou pear orchards situated in the Mid-Columbia region of Oregon and Washington were picked at commercial harvest in 1996 and 1997. Fruit from each orchard were harvested into 10 wood boxes (18 kg of fruit per box, with each box containing approximately 100 fruit) lined with perforated polyethylene bags and stored in air at $-1^{\circ} \mathrm{C}$. Based on visual symptoms described in the Compendium of Apple and Pear Diseases (18), fruit were evaluated for incidence of decay after 3,6, and 8 months. After the 8 -month evaluation, fruit were ripened at $20^{\circ} \mathrm{C}$ for 7 days before a final evaluation of decay. After each evaluation, decayed fruit were removed. The incidence (\%) of each decay type was recorded.

Comparison of decay in nondrenched and thiabendazole-drenched fruit. In 1996 and 1997, d'Anjou pear fruit from 
the same 14 orchards were commercially harvested into bins and transported to a packinghouse. At the packinghouse, the bins of fruit either went directly into $\mathrm{CA}$ storage at $-1.1^{\circ} \mathrm{C}$ in low $\mathrm{O}_{2}\left(1 \% \mathrm{O}_{2}+\right.$ $0.05 \% \mathrm{CO}_{2}$ ), or received a thiabendazole (Mertect 340 F; Syngenta, Greensboro, $\mathrm{NC})$ drench at the registered rate $(525 \mu \mathrm{g}$ a.i./ml) before going into CA storage. Fruit were stored until required for packing and shipping by the packinghouse. The storage period ranged from 4 to 6 months. Fruit then were immersiondumped and floated onto the packing line. Commercially unacceptable fruit showing signs of physical damage or decay were culled during the packing process. Careful records were made by the packinghouse staff of the incidence of culled fruit and the causes of culling in each lot of fruit from each of the orchards. Culled fruit were evaluated for incidence of decay symptoms (18) caused by postharvest pathogens. Incidences of specific decay types in stored fruit from each of the 14 orchards were calculated as follows: the mean total percent incidence of decay recorded for each orchard, multiplied by the mean percent incidence of specific decay type. Decay incidences (\%) in nondrenched and thiabendazole-drenched fruit were recorded.

Data analysis. The Shapiro-Wilk test for normality (29) was performed on all decay incidence (\%) data. For both airstored and CA-stored fruit, incidences of decay data were transformed to logits before being subjected to analysis of variance (SAS/STAT User's Guide; SAS Institute, Inc., Cary, NC). The student's $t$ least significant difference (LSD) was calculated to compare decay means of air-stored fruit, and treatment means of nondrenched and drenched CA-stored fruit.

\section{RESULTS}

Decay in air storage. There was a significant interaction between decay types (gray mold, blue mold bull's eye rot, and Alternaria rot) and year in the air-stored fruit. The mean total decay incidence for 1996 was $44.57 \%$, which was significantly higher than that of 1997 (17.7\%) ( $\mathrm{LSD}_{0.05}$ $=8.76$ ). Incidence of gray mold, blue mold, bull's eye rot, Alternaria rot, Mucor rot, and Coprinus rot detected in the 1996 and 1997 crops are presented in Table 1. The incidence of bull's eye rot was significantly higher than that of all other decay types for 1996. Similar incidences of gray and blue mold in both years and bull's eye rot in 1997 were observed. M. piriformis, Alternaria spp., and Coprinus spp. were responsible for low levels of decay in airstored fruit.

There was no year-decay type interaction in the data presented in Table 2; consequently, data for these 2 years were combined (Table 2). Incidence of decay caused by stem-end infections by $B$. cinerea was higher than calyx-end or puncture infections (Table 2). The combined incidences of stem-end, calyx, and puncture gray mold represent the incidence of decay caused by primary $B$. cinerea infections (Table 3). Secondary spread of decay from primary $B$. cinerea infections to previously uninfected fruit was recorded as secondary gray mold (Table 3 ). There was a significant interaction between both primary and secondary gray mold and year; conse-

Table 2. Incidence of stem, calyx, and puncture gray mold in air-stored 'd'Anjou' pear fruit from orchards in the Mid-Columbia region of Oregon and Washington for the 1996 and 1997 crops $^{\mathrm{x}}$

\begin{tabular}{lccc}
\hline Orchard & Stem-end gray mold & Calyx-end gray mold & Puncture gray mold \\
\hline 1 & 4.09 & 0.31 & 0.92 \\
2 & 3.96 & 1.74 & 1.19 \\
3 & 4.84 & 0.77 & 0.56 \\
4 & 4.40 & 1.15 & 1.18 \\
5 & 1.28 & 0.17 & 0.47 \\
6 & 1.66 & 1.33 & 0.73 \\
7 & 1.87 & 0.70 & 0.35 \\
8 & 3.37 & 1.42 & 0.77 \\
9 & 0.88 & 0.14 & 0.00 \\
10 & 2.22 & 0.40 & 0.55 \\
11 & 1.66 & 0.35 & 0.15 \\
12 & 1.48 & 0.38 & 0.35 \\
13 & 2.91 & 0.32 & 0.97 \\
14 & 1.45 & 1.03 & 0.25 \\
Mean $^{\mathrm{y}}$ & $2.58 \mathrm{a}$ & $0.73 \mathrm{~b}$ & $0.61 \mathrm{~b}$ \\
$\mathrm{LSD}_{0.05}{ }^{\mathrm{z}}$ & 0.419 & $\ldots$ & $\ldots$ \\
\hline
\end{tabular}

${ }^{\mathrm{x}}$ Incidence of decay detected in 10 boxes of d'Anjou pear fruit after 8 months in regular air storage at $-1^{\circ} \mathrm{C}$, followed by a ripening period of 1 week at $20^{\circ} \mathrm{C}$. Data shown as percentage of total fruit evaluated.

y For mean gray mold incidence, values followed by the same letter are not significantly different at $P$ $=0.05$.

${ }^{\mathrm{z}} \mathrm{LSD}=$ least significant difference.

Table 1. Incidence of postharvest decay in air-stored 'd'Anjou' pear fruit from orchards in the Mid-Columbia region of Oregon and Washington for the 1996 and 1997 crops $^{\mathrm{x}}$

\begin{tabular}{|c|c|c|c|c|c|c|c|c|c|c|c|}
\hline \multirow[b]{2}{*}{ Orchard } & \multicolumn{2}{|c|}{ Gray mold } & \multicolumn{2}{|c|}{ Blue mold } & \multicolumn{2}{|c|}{ Bull's eye rot } & \multicolumn{2}{|c|}{ Alternaria rot } & \multicolumn{2}{|c|}{ Mucor rot } & \multirow{2}{*}{$\begin{array}{c}\text { Coprinus rot } \\
1997\end{array}$} \\
\hline & 1996 & 1997 & 1996 & 1997 & 1996 & 1997 & 1996 & 1997 & 1996 & 1997 & \\
\hline 1 & 14.57 & 8.56 & 0.31 & 0.5 & 39.85 & 11.11 & 0.19 & 0 & 0 & 0 & 0 \\
\hline 2 & 25.46 & 5.77 & 0.12 & 2.35 & 21.59 & 16.27 & 0.62 & 0 & 0 & 0.1 & 0 \\
\hline 3 & 12.84 & 15.38 & 0.19 & 3.35 & 36.2 & 6.75 & 0.13 & 0 & 0 & 0 & 0.1 \\
\hline 4 & 16.95 & 12.16 & 0 & 1.6 & 17.37 & 14.28 & 0 & 0 & 0 & 0 & 0.2 \\
\hline 5 & 5.7 & 0.98 & 5.37 & 4.96 & 18.58 & 3.82 & 0.42 & 0.26 & 0.25 & 0 & 0 \\
\hline 6 & 11.04 & 3.77 & 5.74 & 4.53 & 13.05 & 0.72 & 0.39 & 0 & 0 & 0 & 0 \\
\hline 7 & 5.65 & 2.54 & 0.94 & 11.28 & 80.06 & 2.67 & 0 & 0.27 & 0.07 & 0 & 0 \\
\hline 8 & 15.03 & 3.84 & 2.58 & 5.02 & 37.84 & 15.56 & 0.31 & 0.11 & 0 & 0 & 0.13 \\
\hline 9 & 1.59 & 1.45 & 1.96 & 3.36 & 29.36 & 1.53 & 0.91 & 0 & 0 & 0 & 0 \\
\hline 10 & 6.53 & 3.22 & 1.41 & 2.84 & 38.71 & 7.76 & 1.13 & 0.14 & 0 & 0 & 0 \\
\hline 11 & 6.25 & 1.22 & 3.76 & 3.99 & 18.06 & 1.86 & 0.11 & 0.16 & 0 & 0 & 0 \\
\hline 12 & 4.17 & 2.56 & 1.41 & 7 & 35.98 & 3.27 & 1.15 & 0 & 0 & 0 & 0 \\
\hline 13 & 9.74 & 7.43 & 2.1 & 3.21 & 32.29 & 7.23 & 0.56 & 0.15 & 0 & 0 & 0 \\
\hline 14 & 6.92 & 3.99 & 8.22 & 16.51 & 20.26 & 9.53 & 0.94 & 0.28 & 0 & 0 & 0 \\
\hline Mean ${ }^{y}$ & $10.17 \mathrm{~b}$ & $5.21 \mathrm{bcd}$ & $2.44 \mathrm{~cd}$ & $5.04 \mathrm{bcd}$ & $31.37 \mathrm{a}$ & $7.31 \mathrm{bc}$ & $0.49 \mathrm{~d}$ & $0.1 \mathrm{~d}$ & 0.02 & 0.01 & 0.03 \\
\hline $\operatorname{LSD}_{0.05}{ }^{\mathrm{z}}$ & 5.29 & $\ldots$ & $\ldots$ & $\ldots$ & $\ldots$ & $\ldots$ & $\ldots$ & $\ldots$ & $\ldots$ & $\ldots$ & $\ldots$ \\
\hline
\end{tabular}

${ }^{\mathrm{x}}$ Incidence of decay detected in 10 boxes of d'Anjou pear fruit after 8 months in regular air storage at $-1^{\circ} \mathrm{C}$, followed by a ripening period of 1 week at $20^{\circ} \mathrm{C}$. Data shown as percentage of total fruit evaluated.

${ }^{\text {y }}$ For mean gray mold, blue mold, bull's eye rot, and Alternaria rot incidence, values followed by the same letter are not significantly different at $P=0.05$. For Mucor and Coprinus rot, there were insufficient data points for statistical analysis of the data.

${ }^{\mathrm{z}}$ LSD $=$ least significant difference. 
quently, the data for the 2 years were analyzed separately. Incidence of primary $B$. cinerea was significantly higher in 1996 than 1997. Primary and secondary gray mold incidence were similar in both years (Table 3). Secondary B. cinerea infections caused high levels of decay in both years.

Decay incidence in nondrenched and thiabendazole-drenched fruit. There was no year-decay type interaction in the data collected from this experiment; consequently, data for the 2 years were combined. In nondrenched CA-stored fruit, the incidence of gray mold was significantly higher than all other postharvest decay types (Table 4 ). There was no significant difference in incidence of blue mold, $\mathrm{Mu}$ cor rot, bull's-eye rot, or decay caused by other minor pathogens in nondrenched CA-stored fruit. Analysis of the incidence of stem, calyx, and puncture gray mold in nondrenched and drenched fruit revealed a significant treatment (nondrench and drench) effect at the $10 \%$ level; consequently, the $t$ test was adapted to test for significant differences at $P=0.1$ for these data (Table 5). In nondrenched fruit, puncture gray mold incidence was significantly higher than stem-end gray mold, and calyx-end gray mold incidence was significantly lower than stem-end gray mold (Table 5). Incidence of primary gray mold was significantly higher than secondary gray mold in nondrenched fruit (Table 6).

A thiabendazole drench prior to storage significantly reduced the incidence of gray mold but had no effect on the incidence of blue mold, Mucor rot, bull's eye rot, or other minor decay types caused by Alternaria spp. and Cladosporium spp. (Table $4)$. The thiabendazole drench significantly $(P=0.1)$ reduced the incidence of primary

Table 3. Incidence of primary and secondary gray mold in air-stored 'd'Anjou' pear fruit from orchards in the Mid-Columbia region of Oregon and Washington for the 1996 and 1997 crops $^{\mathrm{x}}$

\begin{tabular}{lccccc}
\hline & \multicolumn{3}{c}{ Primary } & & \multicolumn{2}{c}{ Secondary } \\
\cline { 2 - 3 } \cline { 5 - 6 } Orchard & $\mathbf{1 9 9 6}$ & $\mathbf{1 9 9 7}$ & & $\mathbf{1 9 9 6}$ & $\mathbf{1 9 9 7}$ \\
\hline 1 & 7.17 & 3.49 & & 7.41 & 5.06 \\
2 & 10.72 & 3.06 & & 14.73 & 2.7 \\
3 & 6.78 & 6.56 & & 6.06 & 8.82 \\
4 & 7.98 & 5.5 & & 8.97 & 6.66 \\
5 & 3.02 & 0.84 & & 2.68 & 0.13 \\
6 & 6.01 & 1.42 & & 5.03 & 2.34 \\
7 & 4.25 & 1.6 & & 1.4 & 0.93 \\
8 & 7.86 & 3.26 & & 7.17 & 0.57 \\
9 & 1.15 & 0.88 & & 0.44 & 0.56 \\
10 & 3.87 & 2.47 & & 2.66 & 0.75 \\
11 & 3.59 & 0.74 & & 2.66 & 0.48 \\
12 & 3.16 & 1.28 & & 1 & 1.27 \\
13 & 4.11 & 4.59 & & 5.64 & 2.84 \\
14 & 3.64 & 1.83 & & 3.28 & 2.15 \\
Meannnnyyn$_{\text {LSD }_{0.05}}^{\mathrm{z}}$ & $5.24 \mathrm{a}$ & $2.68 \mathrm{~b}$ & & $4.91 \mathrm{a}$ & $2.52 \mathrm{~b}$ \\
\hline
\end{tabular}

$\mathrm{x}$ Incidence of decay detected in 10 boxes of d'Anjou pear fruit after 8 months in regular air storage at $-1{ }^{\circ} \mathrm{C}$, followed by a ripening period of 1 week at $20^{\circ} \mathrm{C}$. Data shown as percentage of total fruit evaluated.

y For mean gray mold incidence, values followed by the same letter are not significantly different at $P$ $=0.05$.

z LSD = least significant difference. gray mold infections of stem ends and punctures, but had no effect on incidence of calyx-end gray mold (Table 5) or secondary gray mold (Table 6). The mean total decay incidence in nondrenched $(3.20 \%)$ and drenched $(1.77 \%)$ fruit was not significantly different $\left(\mathrm{LSD}_{0.05}=1.47\right)$.

\section{DISCUSSION}

We have shown that decay can cause significant postharvest losses in air-stored d'Anjou pear fruit. Postharvest decay may be caused by infection in the orchard $(17,23,31)$, and infections as early as 4 months before harvest cause significant decay in stored d'Anjou pear fruit (31). Postharvest pathogens do not need a wound to infect; however, incidence of decay is higher in wounded pear fruit (31).

In air-stored fruit, gray mold, caused by $B$. cinerea, and blue mold, caused by $P$. expansum, were observed at similar levels of incidence. Incidence of stem-end gray mold was higher than calyx-end and puncture gray mold. The short fleshy stems of d'Anjou pear fruit are particularly susceptible to infection by $B$. cinerea. The abscission zone of d'Anjou pear stems functions as a wound in this cultivar and provides an ideal infection site for both $B$. cinerea and $P$. expansum (31). Secondary infection of fruit from primary $B$. cinerea infections of stems, calyxes, or puncture wounds resulted in nests of decaying fruit. These secondary infections resulted in high levels of decay in air-stored fruit. Recently, Phacidiopycnis piri has been isolated from about $15 \%$ of pear fruit with symptoms similar to gray mold, and additional research is necessary to determine the incidence of this fungus in the Mid-Columbia region of Oregon and Washington $(\mathrm{C}$. Xiao, unpublished data).

The incidence of decay in CA-stored nondrenched d'Anjou pear fruit was low. Nondrenched fruit had significant levels of $B$. cinerea infections at punctures. Thus, wounds resulting from handling of the fruit

Table 4. Incidence of postharvest decay in nondrenched and thiabendazole-drenched controlled-atmosphere (CA)-stored 'd'Anjou' pear fruit from orchards in the Mid-Columbia region of Oregon and Washington for the 1996 and 1997 crops $^{\mathrm{x}}$

\begin{tabular}{|c|c|c|c|c|c|c|c|c|c|c|}
\hline \multirow[b]{2}{*}{ Orchard } & \multicolumn{2}{|c|}{ Gray mold } & \multicolumn{2}{|c|}{ Blue mold } & \multicolumn{2}{|c|}{ Mucor rot } & \multicolumn{2}{|c|}{ Bull's eye rot } & \multicolumn{2}{|c|}{ Other decay } \\
\hline & Nondrenched & Drenched & Nondrenched & Drenched & Nondrenched & Drenched & Nondrenched & Drenched & Nondrenched & Drenched \\
\hline 1 & 6.21 & 2.41 & 0.05 & 0.29 & 0.014 & 0.03 & 0.29 & 0.35 & 0.08 & 0.13 \\
\hline 3 & 0.00 & 1.47 & $\ldots$ & 0.46 & $\ldots$ & 0.05 & $\ldots$ & 0.12 & $\ldots$ & 0.05 \\
\hline 5 & 2.55 & 0.59 & 0.09 & 0.58 & 0.03 & 0.04 & 1.07 & 0.11 & 0.01 & 0.09 \\
\hline 6 & 2.45 & 1.18 & 0.18 & 0.58 & 0.18 & 0.05 & 0.03 & 0.02 & $\ldots$ & 0.03 \\
\hline 7 & 1.37 & 1.16 & 0.11 & 1.21 & 0.02 & 0.05 & 0.37 & 0.46 & 0.05 & 0.06 \\
\hline 8 & 5.49 & 0.69 & 0.16 & 0.52 & 0.31 & 0.01 & 1.96 & 0.1 & 0.05 & 0.02 \\
\hline 9 & 1.17 & 0.32 & 0.17 & 0.15 & 0.02 & 0.001 & 0.55 & 0.06 & 0.04 & 0.03 \\
\hline 11 & 1.65 & 1.69 & 0.1 & 0.36 & 0.012 & 0.02 & 0.17 & 0.11 & 0.05 & 0.03 \\
\hline 12 & 2.05 & 0.46 & 0.22 & 0.42 & 0.03 & $\ldots$ & $\ldots$ & 0.13 & 0.25 & 0.21 \\
\hline 13 & 1.68 & 1.14 & 0.1 & 0.22 & 0.03 & 0.005 & 0.41 & 0.13 & 0.05 & 0.04 \\
\hline 14 & 1.05 & 0.28 & 0.13 & 0.7 & 0.07 & 0 & 0.04 & 0.05 & 0.18 & 0.05 \\
\hline 15 & 1.41 & $\ldots$ & 0.13 & $\ldots$ & 0.03 & $\ldots$ & 0.22 & & 0.04 & $\ldots$ \\
\hline Mean $^{y}$ & $2.26 \mathrm{a}$ & $1.04 \mathrm{~b}$ & $0.13 \mathrm{c}$ & $0.50 \mathrm{bc}$ & $0.07 \mathrm{c}$ & $0.03 \mathrm{c}$ & $0.51 \mathrm{bc}$ & $0.15 \mathrm{c}$ & $0.08 \mathrm{c}$ & $0.07 \mathrm{c}$ \\
\hline $\mathrm{LSD}_{0.05^{\mathrm{z}}}$ & 0.5672 & $\ldots$ & $\ldots$ & $\ldots$ & $\ldots$ & $\ldots$ & $\ldots$ & $\ldots$ & $\ldots$ & $\ldots$ \\
\hline
\end{tabular}

${ }^{\mathrm{x}}$ Incidence of decay detected in pear fruit after CA storage in a commercial packinghouse. Data shown as percentage of total fruit evaluated.

${ }^{y}$ For mean decay incidence, values followed by the same letter are not significantly different at $P=0.05$.

${ }^{\mathrm{z}}$ LSD $=$ least significant difference. 
at harvest and during storage are important sites of infection by $B$. cinerea, particularly in nondrenched fruit. Spotts et al. (36) found that 3\% of d'Anjou pear fruit were wounded during harvest. Although wounds undergo a healing process in storage, they remain susceptible to infection by $M$. piriformis, Penicillium expansum, and $B$. cinerea at $-1^{\circ} \mathrm{C}$ for 2,4 and 8 weeks, respectively (36). Primary infection of fruit wounds (puncture gray mold) and stem ends (stem-end gray mold) by $B$. cinerea caused the highest incidences of decay in nondrenched CA-stored fruit. Incidence of stem-end decay caused by $B$. cinerea was low in CA-stored fruit, supporting the results of Chen et al. (11), who found less stem end decay caused by fungi in d'Anjou pear fruit stored at $-1.1^{\circ} \mathrm{C}$ in low $\mathrm{O}_{2}\left(1 \% \mathrm{O}_{2}+0.05 \% \mathrm{CO}_{2}\right)$ than in fruit stored in air. We observed a low incidence of calyx-end gray mold in CA-stored fruit. The increase in blue mold of cv. Bosc pear fruit in stepwise oxygen storage (12) was not seen in d'Anjou pear fruit here. Incidence of bull's-eye rot caused by Neofabraea spp. was low in CA-stored nondrenched fruit. CA storage, including ultralow-oxygen conditions, has been shown to reduce decay caused by $\mathrm{Neo}$ fabraea spp. $(11,15,17)$.

The application of a prestorage thiabendazole drench significantly reduced the incidence of gray mold; however, it had no effect on the incidence of all other decay types. The mean total decay incidence in nondrenched and drenched fruit was not significantly different. The effect on gray mold was brought about by the significant reduction in stem-end and puncture gray mold. The drench had no effect on calyxend gray mold or secondary gray mold. These findings support those of previous studies showing that good control of $B$. cinerea can be achieved through a single postharvest application of a benzimidazole to pear fruit in the packinghouse $(2,3,9,16)$. Benzimidazoles are effective protectants $(2,27)$ and eradicants (2) of postharvest decay in pome fruit. In a recent study (22), we found a low level of thiabendazole resistance $(0.59 \%)$ in $B$. cinerea isolates from orchard air samples and from d'Anjou pear fruit not exposed to thiabendazole, indicating that $B$. cinerea populations from pear orchards in the MidColumbia region of Oregon and Washington are sensitive to thiabendazole.

A thiabendazole drench had no effect on the incidence of decay caused by P. expansum in CA-stored d'Anjou pear fruit. Sanderson and Spotts (28) recovered a number of Penicillium spp. from drench solutions from pear packinghouses. During drenching, inoculum of $P$. expansum is washed into fruit wounds sustained during harvest and transport to the packinghouse. Consequently, more wounds are exposed to pathogenic $P$. expansum inoculum in drenched than undrenched fruit. Spotts and Cervantes (32) found that 15 to $31 \%$ of pathogenic Penicillium spp. isolates from packinghouse air and dump-tank water were resistant to benomyl. As a result of cross-resistance among the benzimidazole fungicides (14), it is likely that a significant proportion of the drench suspension population of pathogenic $P$. expansum is resistant to thiabendazole. Thus, a combination of increased exposure of wounds to pathogenic Penicillium spp. and survival of resistant pathogenic Penicillium spp. isolates would explain why thiabendazoledrenched d'Anjou fruit had a similar incidence of decay caused by $P$. expansum than nondrenched fruit.

A major problem associated with drenching of fruit prior to storage is the washing of $M$. piriformis spores from dirt and debris onto clean fruit (7). M. piriformis commonly is isolated from pear orchard soil $(25,32,33)$ and from packinghouse dump-tank water (25). M. piriformis is insensitive to both captan and thiabenda-

Table 6. Incidence of primary and secondary gray mold in nondrenched and thiabendazole-drenched controlled-atmosphere (CA)-stored 'd'Anjou' pear fruit from orchards in the Mid-Columbia region of Oregon and Washington for the 1996 and 1997 crops $^{\mathrm{x}}$

\begin{tabular}{lccccc}
\hline & \multicolumn{2}{c}{ Primary } & & \multicolumn{2}{c}{ Secondary } \\
\cline { 2 - 3 } \cline { 5 - 6 } Orchard & Nondrenched & Drenched & & Nondrenched & Drenched \\
\hline 1 & 5.58 & 1.81 & & 0.63 & 0.6 \\
3 & $\ldots$ & 1.35 & & $\ldots$ & 0.12 \\
5 & 2.48 & 0.56 & & 0.07 & 0.03 \\
6 & 2.24 & 1.08 & & 0.21 & 0.1 \\
7 & 1.24 & 1.08 & & 0.13 & 0.08 \\
8 & 5.33 & 0.66 & & 0.16 & 0.03 \\
9 & 1.11 & 0.31 & & 0.06 & 0.008 \\
11 & 1.63 & 1.59 & & 0.02 & 0.1 \\
12 & 2.05 & 0.46 & & $\ldots$ & $\ldots$ \\
13 & 1.54 & 1.12 & & 0.14 & 0.02 \\
14 & 1.03 & 0.28 & & 0.02 & $\ldots$ \\
15 & 1.41 & $\ldots$ & & $\ldots$ & $\ldots$ \\
Mean $^{\mathrm{y}}$ & $2.33 \mathrm{a}$ & $0.94 \mathrm{~b}$ & & $0.16 \mathrm{c}$ & $0.12 \mathrm{c}$ \\
LSD $_{0.05}$ & 0.75 & $\ldots$ & & $\ldots$ & $\ldots$ \\
\hline
\end{tabular}

${ }^{\mathrm{x}}$ Incidence of decay detected in pear fruit after CA storage in a commercial packinghouse. Data shown as percentage of total fruit evaluated.

y for mean gray mold incidence, values followed by the same letter are not significantly different at $P$ $=0.05$.

${ }^{\mathrm{z}} \mathrm{LSD}=$ least significant difference.

Table 5. Incidence of stem, calyx, and puncture gray mold in nondrenched and thiabendazole-drenched controlled-atmosphere (CA)-stored 'd'Anjou' pear fruit from orchards in the Mid-Columbia region of Oregon and Washington for the 1996 and 1997 crops $^{\mathrm{x}}$

\begin{tabular}{|c|c|c|c|c|c|c|}
\hline \multirow[b]{2}{*}{ Orchard } & \multicolumn{2}{|c|}{ Stem-end gray mold } & \multicolumn{2}{|c|}{ Calyx-end gray mold } & \multicolumn{2}{|c|}{ Puncture gray mold } \\
\hline & Nondrenched & Drenched & Nondrenched & Drenched & Nondrenched & Drenched \\
\hline 1 & 2.45 & 0.63 & 0.91 & 0.55 & 2.21 & 0.64 \\
\hline 3 & $\ldots$ & 0.51 & $\ldots$ & 0.23 & $\ldots$ & 0.31 \\
\hline 5 & 1.04 & 0.14 & 0.26 & 0.06 & 1.18 & 0.35 \\
\hline 6 & 0.94 & 0.39 & 0.32 & 0.14 & 0.97 & 0.55 \\
\hline 7 & 0.34 & 0.23 & 0.14 & 0.11 & 0.75 & 0.73 \\
\hline 8 & 1.37 & 0.19 & 1.03 & 0.21 & 2.92 & 0.24 \\
\hline 9 & 0.49 & 0.05 & 0.15 & 0.08 & 0.48 & 0.17 \\
\hline 11 & 0.91 & 0.86 & 0.14 & 0.13 & 0.57 & 0.6 \\
\hline 12 & 0.19 & 0.08 & 0.03 & 0.08 & 1.82 & 0.29 \\
\hline 13 & 0.82 & 0.62 & 0.31 & 0.12 & 0.41 & 0.38 \\
\hline 14 & 0.19 & 0.08 & 0.32 & 0.11 & 0.52 & 0.09 \\
\hline 15 & 0.46 & $\ldots$ & 0.32 & $\ldots$ & 0.64 & $\ldots$ \\
\hline Mean ${ }^{y}$ & $0.84 \mathrm{~b}$ & $0.34 \mathrm{c}$ & $0.36 \mathrm{c}$ & $0.17 \mathrm{c}$ & $1.13 \mathrm{a}$ & $0.40 \mathrm{c}$ \\
\hline $\operatorname{LSD}_{0.05^{\mathrm{z}}}$ & 0.283 & $\ldots$ & $\ldots$ & $\ldots$ & $\ldots$ & $\ldots$ \\
\hline
\end{tabular}

${ }^{\mathrm{x}}$ Incidence of decay detected in pear fruit after CA storage in a commercial packinghouse. Data shown as percentage of total fruit evaluated.

${ }^{y}$ For mean gray mold incidence, values followed by the same letter are not significantly different at $P=0.1$.

${ }^{\mathrm{z}} \mathrm{LSD}=$ least significant difference. 
zole $(1,8,9,26)$ and no fungicidal control for M. piriformis has been found (34). For this reason, the majority of packers apply thiabendazole as a line spray $(19,20)$. Very low levels of decay caused by M. piriformis were detected in both air-stored and CA-stored fruit. A thiabendazole drench did not significantly reduce the incidence of Mucor rot in CA-stored fruit, reflecting the insensitivity of $M$. piriformis to this fungicide $(9,26)$. The incidence of Mucor rot detected in culled fruit from CA storage, for both undrenched and drenched fruit, may be artificially low because this rot can cause severe disintegration of the fruit. A significant proportion of fruit with Mucor rot is removed and discarded as the fruit floats out of the storage bins (presort) after immersion dumping and does not appear on the cull line where the culled fruit inspected.

These results support the current recommendations of a single postharvest application of thiabendazole to control postharvest gray mold in d'Anjou pear fruit. These recommendations are in compliance with the recognized method for reducing the selection pressure on an at-risk fungicide by restricting its use to one or two critical periods (41). However, packers need to be aware of the potential risk of increased decay caused by Penicillium spp. in drenched pear fruit. This risk would be considerably reduced by the application of fungicide in a line spray.

Recent research has indicated the need for a more integrated approach to the control of postharvest decay in pear fruit (37), including use of preharvest strategies $(23,38)$. Combination of yeast biological control agents with low dosages of thiabendazole has been shown to effectively control decay caused by $B$. cinerea, $P$. expansum, $M$. piriformis, and Neofabraea spp. in d'Anjou pear $(9,10,39)$. Inclusion of biological control in this integrated approach to decay control would reduce the selection pressure from thiabendazole and, possibly, provide better control of blue mold in areas where incidence of resistance in the $P$. expansum population is high.

\section{ACKNOWLEDGMENTS}

We thank the Winter Pear Control Committee for partial funding of the research.

\section{LITERATURE CITED}

1. Anonymous. 1992. Management practices to minimize postharvest decay of apples and pears. Tree Fruit Postharvest J. 3:5-8.

2. Banyal, D. K., and Sharma, R. L. 1994. Effect of postharvest fungicidal treatments on gray mould rot of pear caused by B. cinerea. Plant Dis. Res. 9:172-174.

3. Ben-Arie, R., and Guelfat-Reich, S. 1973. Preharvest and postharvest applications of benzimidazoles for control of storage decay of pears. HortScience 8:181-183.

4. Bertrand, P. F., MacSwan, I. C., Rackham, R. L., and Moore, B. J. 1977. An outbreak of side rot in Bosc pears in Oregon. Plant
Dis. Rep. 61:890-893.

5. Bertrand, P. F., and Saulie-Carter, J. L. 1978. The occurrence of benomyl-tolerant strains of Penicillium expansum and $B$. cinerea in the Mid-Columbia region of Oregon and Washington. Plant Dis. Rep. 62:302-305.

6. Bertrand, P. F., and Saulie-Carter, J. L. 1979. Postharvest decay control of apples and pears after immersion dumping. Ore. State Univ. Exp. Stn. Spec. Rep. 545.

7. Bertrand, P. F, and Saulie-Carter, J. L. 1980. Mucor rot of pears and apples. Ore. State Univ. Exp. Stn. Spec. Rep. 568.

8. Bollen, G. J., and Fuchs, A. 1970. On the specificity of the in vitro and in vivo antifungal activity of benomyl. Neth. J. Plant Pathol. 76:299-312.

9. Chand-Goyal, T., and Spotts, R. A. 1996. Control of postharvest pear diseases using natural saprophytic yeast colonists and their combination with a low dosage of thiabendazole. Postharvest Biol. Technol. 7:51-64.

10. Chand-Goyal, T., and Spotts, R. A. 1997. Biological control of postharvest diseases of apple and pear under semi-commercial and commercial conditions using three saprophytic yeasts. Biol. Control 10: 199-206.

11. Chen, P. M., Spotts, R. A., and Mellenthin, W. M. 1981. Stem-end decay and quality of low oxygen stored d'Anjou pears. J. Am. Soc. Hortic. Sci. 106:695-698.

12. Chen, P. M., Spotts, R. A., Varga, D. M., and Cervantes, L. A. 1995. Ripening behavior and combined fungicide and prestorage heat effects on decay control of 'Bosc' pears in air or stepwise low oxygen storage. Postharvest Biol. Technol. 6:235-248.

13. de Jong, S. N., Levesque, C. A., Verkley, G. J. M., Abeln, E. C. A., Rahe, J. E., Braun, P. G., and Jong, S. N. 2001. Phylogenetic relationships among Neofabraea species causing tree cankers and bull's-eye rot of apple based on DNA sequencing of ITS nuclear rDNA, mitochondrial rDNA, and the beta tubulin gene. Mycol. Res. 105: 658-669.

14. Delp, C. J. 1995. Benzimidazoles and related fungicides. Pages 291-303 in: Modern Selective Fungicides-Properties, Applications, Mechanisms of Action. 2nd ed. H. Lyr, ed. Gustav Fisher Verlag, Stuttgart, Germany.

15. Edney, K. L. 1964. The effect of the composition of the storage atmosphere on the development of rotting of Cox's Orange Pippin apples and the production of pectolytic enzymes by Gloeosporium spp. Ann. Appl. Biol. 54:327334.

16. Gurer, M., and Maden, S. 1990. Chemical control of storage rots in Ankara pears. J. Turk. Phytopathol. 19:31-39.

17. Huberdeau, D., and Trillot, M. 1997. Fruit tree arboriculture - Pathogens, residues and conservation of apples and pears. Phytoma 50:46-48.

18. Jones, A. L., and Aldwinckle, H. S., eds. 1990. Compendium of Apple and Pear Diseases. American Phytopathological Society Press, St. Paul, MN.

19. Kupferman, E. 1998. Postharvest applied chemicals to pears: a survey of pear packers in Washington, Oregon and California. Tree Fruit Postharvest J. 9:3-24.

20. Kupferman, E., Spotts, R., and Sugar, D. 1995. Practices to reduce postharvest pear diseases. Tree Fruit Postharvest J. 6:18-23.

21. Lennox, C. L., and Spotts, R. A. 1997. Botrytis gray mold as a postharvest pathogen in d'Anjou pear. Pages 93-95 in: Proc. 13th Annu. Washington Tree Fruit Postharvest Conf. E. Kupferman, ed. Washington State Horticultural Association, Wenatchee.

22. Lennox, C. L., and Spotts, R. A. 2003. Sensitivity of populations of Botrytis cinerea from pear-related sources to benzimidazole and di- carboximide fungicides. Plant Dis. 87:645649.

23. Lennox, C. L., Spotts, R. A., and Cervantes, L. A. 2003. Populations of Botrytis cinerea and Penicillium spp. on pear fruit, and in orchards and packinghouses, and their relationship to postharvest decay. Plant Dis. 87: 639-644.

24. Maas, J. L., and MacSwan, I. C. 1970. Postharvest fungicide treatments for reduction of Penicillium decay of Anjou pears. Plant Dis. Rep. 54:887-890.

25. Mari, M. Cembali, T., Casalini, L., and Pratella, G. C. 2000. Mucor species in orchard soil-population dynamics and pathogenicity on pear fruit. Eur. J. Plant Pathol. 106:449454.

26. Michailides, T. J., and Spotts, R. A. 1990 Postharvest diseases of pome and stone fruits caused by Mucor piriformis in the Pacific Northwest and California. Plant Dis. 74:537543.

27. Ndubizu, T. O. C., and Blanpied, G. D. 1971. Further evaluation of thiabendazole as a postharvest fungicide for apples. Plant Dis. Rep. 55:791-794.

28. Sanderson, P. G., and Spotts, R. A. 1995. Postharvest decay of winter pear and apple fruit caused by Penicillium. Phytopathology 85:103-110.

29. Shapiro, S. S., and Wilk, M. B. 1965. An analysis of variance test for normality (complete samples). Biometrika 52:591-611.

30. Spalding, D. H. 1970. Postharvest use of benomyl and thiabendazole to control blue mold rot development in pears. Plant Dis. Rep. 54:655-657.

31. Spotts, R. A. 1985. Effect of preharvest pear fruit maturity on decay resistance. Plant Dis. 69:388-390.

32. Spotts, R. A., and Cervantes, L. A. 1986. Populations, pathogenicity, and benomyl resistance of Botrytis spp., Penicillium spp., and Mucor piriformis in packinghouses. Plant Dis. 70:106-108.

33. Spotts, R. A., and Cervantes, L. A. 1994 Effects of soil moisture, temperature and nutrient availability on the population dynamics of Mucor piriformis. Mycol. Res. 98:342-346.

34. Spotts, R. A., Holmes, R. J., and Washington, W. S. 1988. Sources of spores and inoculum concentrations related to postharvest decay of apple and pear. Australas. Plant Pathol. 17:4857.

35. Spotts, R. A., and Peters, B. B. 1980. Chlorine and chlorine dioxide for control of d'Anjou pear decay. Plant Dis. 64:1095-1097.

36. Spotts, R. A., Sanderson, P. G., Lennox, C. L., Sugar, D., and Cervantes, L. A. 1998. Wounding, wound healing and staining of mature pear fruit. Postharvest Biol. Technol. 13:27-36.

37. Sugar, D., Richardson, D. G., Chen, P. M., Spotts, R. A., Roberts, R. G., and ChandGoyal, T. 1998. Advances in improving the postharvest quality of pears. Acta Hortic. 475:513-526.

38. Sugar, D., and Spotts, R. A. 1995. Preharvest strategies to reduce postharvest pear decay. Tree Fruit Postharvest J. 6:13-14.

39. Sugar, D., and Spotts, R. A. 1999. Control of postharvest decay in pear by four laboratorygrown yeasts and two registered biocontrol products. Plant Dis. 83:155-158.

40. U.S. Department of Agriculture. 1971. Market diseases of apples, pears and quinces. Agric. Res. Serv. Agric. Handb. 376.

41. Wade, M. 1988. Strategies for preventing or delaying the onset of resistance to fungicides and for managing resistance occurrences. Pages 14-15 in: Fungicide Resistance in North America. C. J. Delp, ed. American Phytopathological Society Press, St. Paul, MN. 